\title{
Correction to: Analysis of cardiac monitoring and safety data in patients initiating fingolimod treatment in the home or in clinic
}

Brandon Brown ${ }^{1}$, Jamie L. Weiss ${ }^{1}$, Scott Kolodny ${ }^{1}$, Xiangyi Meng ${ }^{1}$, Ian M. Williams ${ }^{2}$ and John A. Osborne ${ }^{3 *}$

\section{Correction to: BMC Neurol (2019) 19:287 \\ https://doi.org/10.1186/s12883-019-1506-0}

Following publication of the original article [1], an error was noted regarding the year found in the paragraph of the Background section.

The sentence should read 'As of 31 August 2019, it is estimated that more than 293,400 patients have been treated with fingolimod, corresponding to approximately 714,600 patient-years of exposure (data on file, Novartis Pharmaceuticals Corporation)'.

\section{Author details}

${ }^{1}$ Novartis Pharmaceuticals Corporation, One Health Plaza, East Hanover, NJ 07936, USA. ${ }^{2}$ Oxford PharmaGenesis, Tubney Warren Barn, Tubney, Oxford OX13 5QJ, UK. ${ }^{3}$ State of the Heart Cardiology, Plaza 1, Medical Pkwy. N Suite

103, Dallas, TX 75234, USA.

Published online: 21 December 2019

\section{Reference}

1. Brown B, Weiss JL, Kolodny S, Meng X, Williams IM, Osborne JA. Analysis of

cardiac monitoring and safety data in patients initiating fingolimod

treatment in the home or in clinic. BMC Neurol. 2019;19:287.

https://doi.org/10.1186/s12883-019-1506-0.

The original article can be found online at https://doi.org/10.1186/s12883019-1506-0

* Correspondence: josborne@sothcardiology.com

${ }^{3}$ State of the Heart Cardiology, Plaza 1, Medical Pkwy. N Suite 103, Dallas, TX 75234, USA

Full list of author information is available at the end of the article

(c) The Author(s). 2019 Open Access This article is distributed under the terms of the Creative Commons Attribution 4.0 International License (http://creativecommons.org/licenses/by/4.0/), which permits unrestricted use, distribution, and reproduction in any medium, provided you give appropriate credit to the original author(s) and the source, provide a link to the Creative Commons license, and indicate if changes were made. The Creative Commons Public Domain Dedication waiver (http://creativecommons.org/publicdomain/zero/1.0/) applies to the data made available in this article, unless otherwise stated. 